\title{
Moodle Cloud as the Developing Listening E-Learning Media in SMP Negeri 7 Medan
}

\author{
Nora Ronita Dewi ${ }^{1}$, Juli Rachmadani Hasibuan ${ }^{2}$, Masitowarni Siregar ${ }^{3}$, Anggraini Thesisia

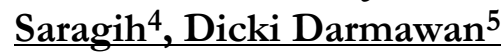 \\ 1,2,3,4,5Universitas Negeri Medan, Indonesia \\ Email: noraxavierre@gmail.com
}

\begin{abstract}
The study was conducted to establish listening media for Grade VII of Junior High School Students. Research and Development (RED) was conducted in the study. Listening media was designed through six stages namely. (1) Gathering information and data; (2) analyzing data; (3) designing materials; (4) validating by experts; (5) revising; and (6) final product. The data were collected by conducting interview to English teacher and distributing questionnaire to one class of grade VII consisting of 30 students to get the students' needs in improving listening skill. The interview and questionnaire results showed that the students needed English Listening Media which could motivate and encourage the students to speak actively in English since both listening and speaking are integrated each other. The authority had assessed the media produced. The outcome of the research was an E-learning media named Moodle Cloud. The rate of assessment of the product was $93.55 \%$. Therefore all the features were categorized as a relevant and effective media in improving students' listening skill.
\end{abstract}

Keywords: Moodle Cloud; English listening media; research and development (RED)

\section{Introduction}

Many schools nowadays have already facilitated their school with an internet connection and also computer laboratory. But this advancement is not utilized well, because they only used weekly for a single classroom. More over the use of the laboratory is only intended to specific subject related to computer operation. This advancement actually must use extensively in every subject to support the learning process.

In teaching English especially for listening skill at school, teachers keep finding problem relating to master English listening skill. The students' feeling to get bored and not interested in learning because of the monotone method from the teacher becomes a real problem in education system nowadays. Moreover the material and the using media do not facilitate and support to the student's needs and interests. For this matters, the teacher should find an appropriate media which help them to motivate the students to learn English in particular spoken language.

Comparing between the traditional learning and e-learning in some schools, students in traditional learning tend to be uninterested with the subject because there is no interesting thing in learning process rather than students who are facilitated with e-learning media. Some various media and activities become an effective way in teaching listening skill. A very good and sophisticated learning media can motivate and encourage them to listen in English. It is also important to increase students' interests by making them enjoy the teaching and learning processes in the classroom. One of e-learning media that can provide the facility to fulfill the needs in learning process is Moodle cloud. One of the school that observed by the researcher is SMPN 7 Medan. Based on the observation, the teaching and learning activities does not use computer laboratory as the supportive features to help students in learning English. 
The research was held in SMPN 7 Medan. The reason why the researcher chosen the school as the subject of the study was because the media used by the teacher was still not enough to encourage the students' interests and effective enough for students to learn or develop their listening skill. Handbook and worksheets (LKS) were the only media and material that teachers used to teach the students to encourage and develop their listening skill.

Those reason were found based on the preliminary observation and the data were collected by the researcher about students' listening ability of grade VII at SMP Negeri 7 Medan and in odd semester.

\section{Review of Literatures}

\subsection{The Nature of Listening}

Listening is an essential skill for people who learn language. It is the very first skill that should be managed by people who learn language. Nunan (2003) stated that listening is an active, purposeful process of making sense of what we hear. The explanation shows that listening plays a significant role in communication using English. In verbal communication, listening is an important skill for those who learn the language especially English. According to Rost (2002) effective listening involves a conscious shift in intention while listening. Commonly effective listening becomes the foundation of strong relationships with others, home, social, education, and in the workplace. Chastain (1971) stated that the listening comprehension aim is to comprehend the language through normal speed in an automatic condition or while communicating. Learning is determining the difficulty levels of tasks that is affected by a distinguish actor. There are a number of factors that interact with each other's, so that they are assumed as the variables key in designing of the listening tasks (Robinson, 2001)

\subsection{Descriptive Text}

Gerot and Wignell (1995) stated that descriptive text is one of genres which is aimed to describe a particular person, place or things. Every genre text has a specific characteristic to show its social function. The social function of descriptive text is to portray a particular characteristic of a person, place or thing which leads the reader's mind to form them. Dirgeyasa (2016: 58) explained the organization of the text and descriptive writing components, as follows: Identification, description.

\subsection{Media}

Media represents in portraying the communication. Bakri (2011) states that media is a plural form of medium deriving from Latin word medius that has meaning "middle". Kamaludin (2009) states that media is facilities, resources or tools used by people to produce message or information. Media is a facilities that should be utilized maximally due to develop the student's motivation in learning. Learning tools basically defined as all tools that have a function to help the teacher to deliver learning material to the students in order to achieve the learning goal. It is relevant to Daryanto (2010) who stated that instructional tools is all instruments which can provide message and trigger students' interests in learning English especially in developing listening skill.. There are 7 kinds of media. The basic principles based on the nature of the lesson such as, sound, visual and act. The classifications are; (a) a graphic media; (b) display media; (c) three dimensional media; (d) projected media; (e) audio media; (f) video tool; and (g) activity media. (Mahajan, 2012).

\subsection{Moodle Cloud}

In the last decade, the teaching of EFL listening in Indonesia has been closely connected to the concept of e-learning which is emphasized to help the teachers in developing and utilizing the advancement of technology. Moodle cloud is an on line class type which is resourceful as the variation media in teaching and learning process. Cole and Foster (2008) defined Moodle as the 
abbreviation of Modular Object-Oriented Dynamic Learning Environment which means the place for the learning process may be dynamic using the model oriented with the object. Modular ObjectOriented Dynamic Learning Environment (Moodle) is a instructional tool type developed so that we can create VLEs. Moodle Cloud is a cloud based E-Learning platform for creating learning communities around educational subjects and activities. Cole and Foster (2007) also defined Moodle as a verb that contains a process and acts like a game that can be fun and intended to add creativity and knowledge.

\section{Research Methods}

A developmental design was utilized in the study. Following Borg and Gall, The Research and Development (R\&D) was intended to establish and asses' education outcome such as curriculum, modules. Syllabus, textbooks, lesson plan, media, instruments, assessment, etc. Borg and Gall stated that (2003:569) that the research findings was used to develop new products and procedures. This research was conducted in SMP Negeri 7 Medan which was located in Jln. H. Adamalik Medan. The subject of this study was one class of grade VII students at SMP Negeri 7 Medan. In collecting the data, researcher conducted the research using two instruments, the first was using questionnaires and the second was using interview. The data which was used in this study were: Questionnaire and Interview. In seeking the information about the problem that the students and teacher face, this interview was given to the teacher and some students. It was intended to know what was the appropriate media that should be applied to solve the problem. The questionnaires were addressed to the sample provided about the students' need in five options by which students had to choose one of them to get the information on the establishment of Moodle Cloud media in learning listening. In collecting the data, the researcher collected the data by using qualitative and quantitative approach. The qualitative data were collected from the questionnaires which were obtained from the students and interview provided to the teacher and some students, while the quantitative data were collected from the questionnaires in number and percentage form. In the data analysis, these two forms were the references that being used. From the questionnaire and interview were given to some students and teacher, contributed the data. The data that were collected and analyzed were important in developing listening skill because it could evaluate and assess what the student's needs in listening. Two data analyses divided the data, the qualitative analysis and the quantitative analysis. In form of percentage the questionnaires contributed to the quantitative data. The research method was adapted from Borg and Gall's research and development theory (2003:569). There were a number of changes which became 6 steps of R \& D cycle. This Moodle cloud was an efficient tool helping the students in grade VII students of SMPN 7 Medan to inctrease and to establish the students' media of oral receptive skill since it was created for the students' needs. The six steps were: (1) Gathering Data and Information; (2) Data Analysis; (3) Media Design; (4) Validating to Experts; (5) Revising,; and (6)Final Product.

\section{Discussion}

There were six steps needed to be completed in to develop listening media. They were such as (1) collecting information and facts; (2) need analysis; (3) designing media; (4) validating to experts; (5) revising; and (6) final product. Initial data from the seventh grade at SMP Negeri 7 Medan used only book produced by the authority that was entitled "When English Rings a Bell" and a media which was a video or sound recording as helping tools to produce the oral receptive skills. However, the students were still lack of ability in mastering listening skill. Since the teacher had not implemented a way in improving the students' motivation itself. Then, the teacher also tended to use traditional learning that made the situation instructional process boring. Therefore, the students needed a fresh way such as the media in increasing their interest. 
Since comparing between the traditional learning and e-learning in several schools, students in traditional learning tend to be uninterested with the subject because there is no interesting thing in learning process rather than students who are facilitated through an e-learning media. Some various media and activities become an effective way in teaching listening skill. A good and efficient learning media can motivate and encourage them to listen in English. Not only lesson and helpful media, but it is crucial to increase the students' interest in the instructional process.

30 students in seventh grade at SMP Negeri 7 Medan were given the questionnaire. The questionnaire provided 12 questions that given to the students. Students' needs analysis was divided into two major needs: students' target needs and learning needs. In addition, necessities, lacks and wants of the learners were covered in target needs, while the learning input, teacher's role, students' role and the learning setting were covered in learning needs.

Based on the data obtained, it knew that the students demand to have better media which is innovative and attractive that can encourage the students to learn English, listen and communicate. Therefore, the study developed Moodle Cloud as an e-learning media. Based on the result of the study validated by the experts, it was known that the validation score from the first expert was $91,4 \%$ and from the second expert was 95,7\% and it was categorized as relevant to fulfill the students' need in improving listening ability of the students. Overall, the score of media validation was $93.55 \%$.

The study aimed to find out the students' need in order to develop the appropriate media for the seventh grade students at SMP Negeri 7 Medan. The developed media was appropriate and related to the students' interest based on their needs analysis. Since the problem faced in teaching listening skill was the lack of students' ability in understanding meaning. When the students were also asked to improve the students' ability in English, they were not interested because the teaching method made them to fell bored. Therefore, the students needed a fresh way to increase their motivation in learning English especially in mastering listening skill.

One of the ways to improve the students' learning motivation could be analyzing their needs based on their interest. It was intended to develop their ability and skill in learning English, especially listening skill. The findings of this study showed that the students need more motivation to learn English subject and an attractive media could motivate them. Therefore media is an effective solution to fulfill the students' needs. Comparing between the traditional learning and elearning in several school, students in traditional learning tend to be uninterested with the subject because there is no interesting thing in learning process rather than students who are facilitated with e-learning media. Some various media and activities become an effective way in teaching listening skill. An interesting and efficient learning media can motivate and encourage them to listen in English. Not only lesson on an interesting media, but it is also important to increase the students' interest by enjoying the teaching and learning processes in the classroom.

In addition, even though the language proficiency in determining the listening skills might be affected by many factors, media especially a listening media also played an important role. The result of this study suggested teacher to use an attractive, innovative, and interesting media based on the students' needs, wants, and interests.

Therefore, the researcher had developed an interactive media namely Moodle Cloud. Moodle Cloud is a cloud based E-Learning platform for creating learning communities around educational subjects and activities. Cole and Foster (2007) also defined Moodle as a verb that contains a process and acts like a game that can be fun and intended to add the creativity and 
knowledge. Then, based on the result of validation, the validation score from the first validator was $91,4 \%$ and from the second validator was $95,7 \%$ and it was categorized as a relevant media.

Based on data above, it was known that Moodle Cloud is a relevant media in improving listening ability of the students. Since the media can increase the students learning motivation which can solve the students' problem in mastering that skill.

\section{Conclusion}

According to the data analysis, it was known that students in SMP Negeri 7 Medan is not interested in the existing listening media. This is due to the fact that the product used by the teacher was not good and duly. Moreover, it is uninteresting to motivate and raise the interest of the students to participate actively in listening learning process. The students may find a reality that it is difficult to listen a foreign language without the appropriate or authentic sound which eventually brings them to be passive in learning process. They demand to have a better media in order to support the learning process. In addition, they want to have an innovative, interesting and attractive media that can motivate them to learn, listen and communicate. Developing the new interesting and appropriate listening media may be a solution for them. This new product of listening media was based on the students' needs and make students more interest and active in learning. This condition also may ease the students to learn and listen the audio through Moodle Cloud. Cole and Foster (2007) defined Moodle as a verb that contains a process and acts like a game that can be fun and intended to add the creativity and knowledge. E-learning Moodle cloud follows the R \& D phases raised by Borg and Gall (2003) simplified into, (1) Gathering Data and Information; (2) Need Analysis; (3) Designing Media; (4) Validating by expert; (5) Revising; (6) Final Product. Based on the result of the study, an E-learning media which is Moodle Cloud and all the features were categorized as a relevant media since the validation score of the media was $93.55 \%$. The score of validation was obtained from the experts. The first expert was $91,4 \%$ and the second expert was $95,7 \%$. Therefore, the media was an appropriate media in improving listening ability of the students. Since comparing between the traditional learning and e-learning in several schools, students in traditional learning tend to be uninterested with the subject because there is no interesting thing in learning process rather than students who are facilitated with e-learning media. Some various media and activities become an effective way in teaching listening skill. An interesting and efficient learning media can motivate and encourage them to listen in English. Not only lesson on an interesting media, but it is also important to increase the students' interest by enjoying the teaching and learning processes in the classroom so that the objective of the study could be achieved.

\section{References}

Arsyad, A. (2013). Media Pembelajaran. Jakarta: PT. Raja Grafindo Persada

Bakri, H. (2011). Jurnal MEDTEK, Volume 3, Number 2, October 2011. Desain Media PembelajaranAnimasiBerbasis Adobe Flash CS3 PadaMatakuliahInstalasiListrik 2. (online). ( https://dokumen.tips/documents/jurnal-hasrul-bakri.html) accessed on March 30, 2019.

Borg, W. R., \& Gall, M. D. (2003). Research and Development In Education. Cambridge: Cambridge University Press.

Chastain, K. (1971). The Development of Modern Language Skills: Theory to Practice. Philadelphia: Center for Curriculum Development.

Cole, J., Foster, H. (2007). Using Moodle.Second Edition. O’Reilly Media Inc. USA.

Daryanto. (2010). Media Pembelajaran (Perananya Sangat Penting Dalam Mencapai Tujuan Pembelajaran).Yogyakarta: Gava Media. 
Dirgeyasa. (2016). College Academic Writing A Genre Based Perspective. Jakarta: Kencana

Gerrot, L., \& Peter, W. (1995). Making Sense of Functional Grammar. Sydney: Antepodean Educational Enterprises.

Kamaludin. (2009). The Use of Media in Teaching and Learning. (Online). (http://www.authorstream.com/Presentation/kamal_bali1-133642usemedia-teachinglearnin-instruction-definition-consideration advantagestypes-learning- educationppt-powerpoint/ ) accessed on March 30, 2019. 